\title{
Homatula guanheensis sp. nov. (Teleostei: Nemacheilidae), a new species of loach from Henan Province, China
}

\author{
Chuanjiang Zhou ${ }^{\ddagger}$, Wenwen Ma ${ }^{\ddagger}$, Xi Wang ${ }^{\ddagger}$, Yongtao Tang ${ }^{\ddagger}$, Xiaoling Meng ${ }^{\ddagger}$, Guoxing Nie ${ }^{\ddagger}$ \\ ‡ Engineering Technology Research Center of Henan Province for Aquatic Animal Cultivation, College of Fisheries, Henan
} Normal University, Xinxiang City, China

Corresponding author: Chuanjiang Zhou (chuanjiang88@163.com), Guoxing Nie (niegx@htu.cn)

Academic editor: Yahui Zhao

Received: 26 Feb 2021 | Accepted: 01 Jun 2021 | Published: 16 Jun 2021

Citation: Zhou C, Ma W, Wang X, Tang Y, Meng X, Nie G (2021) Homatula guanheensis sp. nov. (Teleostei: Nemacheilidae), a new species of loach from Henan Province, China. Biodiversity Data Journal 9: e65130. https://doi.org/10.3897/BDJ.9.e65130

ZooBank: urn:Isid:zoobank.org:pub:9C0170DE-C5CB-4500-AD43-DD1094319916

\begin{abstract}
Background

The genus Homatula belongs to the order Cypriniformes and family Nemacheilidae. Nichols (1925) set up the genus as a subgenus of Barbatula by the type species of Nemacheilus potanini. Currently, it is recognised as a valid genus. Nineteen valid species have been already reported in the drainage of the Yellow, Yangtze, Pearl, Lancang, Red and Nujiang Rivers. $H$. variegata, $H$. longidorsalis, $H$. berezowskii and $H$. potanini are distributed in the Yangtze River drainage in China. $H$. laxiclathra is mainly distributed in the Weihe River, a tributary of the Yellow River. The remaining species are mainly distributed in the rivers of Yunnan Province.
\end{abstract}

\section{New information}

Homatula guanheensis sp. nov., a new species, is described from the Guanhe River of the HanJiang River drainage (a tributary of the Yangtze River), Xixia County, Henan Province, 
China. It can be distinguished from its congeners by a combination of the following characters: the vertical brown bars on the body are wider than their interspaces, numbering 19-22; predorsal body partially scaled; the lateral line complete; adipose crest on caudal peduncle not reaching forward; the position of the anal-fin origin and the intestinal form. The new species displays distinct molecular divergence in the Cytochrome oxidase I (COI) and Cytochrome b (Cyt $b)$ genes.

\section{Keywords}

Homatula, morphology, Hanjiang River drainage, taxonomy

\section{Introduction}

The Nemacheilid genus Homatula was established by Nichols in 1925 as a subgenus of Barbatula, based on the type species Nemacheilus potanini. Species from Homatula are small-size benthic fishes that are distributed in the drainage of the Yellow, Yangtze, Pearl, Lancang, Nujiang and Red Rivers. Some researchers have treated Homatula as a synonym of Paracobitis according to its adipose-crest (Chu and Chen 1990, Ding and Deng 1990, Min et al. 2010, Zhou and He 1993, Zhu 1989, Zhu and Cao 1988, Zhu and Wang 1985). However, the type species of Paracobitis was described from western Asia and these had a large geographical gap with the Chinese species (Bănărescu and Nalbant 1995, Kottelat 1990). Therefore, we accept the opinion of species in western Asia as Paracobitis and all species in China as Homatula (Kottelat 1990, Bănărescu and Nalbant 1995). Nine species of Homatula have been reported from China before 2010. Homatula erhaiersis (Zhu and Cao, 1988) was treated as a synonym of $H$. anguillioides (Zhu and Wang, 1985) in recent studies by the comparison of phylogenetic analysis and morphological characteristics (Min et al. 2012, Endruweit et al. 2018). In addition, an increasing number of new species of Homatula have been reported in recent years: $H$. disparizona (Min et al. 2013) was the first recorded species of Homatula from the Red River; H. wenshanensis (Yang et al. 2017) and H. coccinocola (Endruweit et al. 2018) were also found in the Red River; $H$. change (Endruweit 2015) was found in the upper Black River Basin; H. wuliangensis (Min et al. 2012) and H. pycnolepis (Hu and Zhang 2010) were collected from the Lancang River drainage; $H$. nanpanjiangensis (Min et al. 2010) was reported from the Pearl River; $H$. laxiclathra (Gu and Zhang 2011) was found in the Wei-He River of the Yellow River drainage in Shaanxi Province and three new species of Homatula were identified in the upper Salween River (Li et al. 2019).

The morphological variation of Homatula in the upper Yellow River drainage, the uppermiddle reaches of Yangtze River drainage and the upper Pearl River drainage was investigated by Zeng et al. in 2012. However, the taxonomic status of the specimens from the Hanjiang River of the middle Yangtze River drainage were undetermined (Zeng et al. 2012). The specimens of Homatula from the Guanhe River (a tributary of the Han River) were collected during the investigation of fishery resources in Xixia County, Henan Province. Morphological data and DNA taxonomy ( $\mathrm{COI}$ and Cyt $b$ ) were used to identify the 
samples and the analysis found differences with the species that had been previously discovered. An unnamed species, different from congeners, is described in this paper.

\section{Materials and methods}

All specimens were examined and stored in the collection of the College of Fisheries, Henan Normal University, Xinxiang, Henan Province, China. For morphological analysis, 10 specimens were fixed in $10 \%$ formalin. All measurements and counts were made following Kottelat (1990). Measurements were made point to point with digital calipers to the nearest $0.1 \mathrm{~mm}$. X-ray films were used to count simple fin rays. Comparative morphometry was examined using PCA in IBM SPSS Statistics 22.0. The PCA analysis was processed using log-transformed morphometric data of percent of Standard Length $(\mathrm{SL})$ in the variance-covariance matrix. To compare molecular characters, eighteen specimens were fixed in $95 \%$ ethanol and total genomic DNA was extracted from muscle tissue using standard phenol-chloroform extraction protocols (Sambrook et al. 1989). Two pairs of primers were used to amplify segments of $\mathrm{COI}$ and Cyt $b$ by the polymerase chain reaction. The $\mathrm{COI}$ primers were designed with reference to other Osteichthyes $\mathrm{COI}$ gene sequences: Fish-CO I-F (5'-TCT CAA CCA ACC ATA AAG ACA TTGG-3'); Fish-CO I-R (5'TAT ACT TCT GGG TGC CCA AAG AAT CA-3'). The Cytb gene primers were designed as GluF (5'-AAC CAC CGT TGT ATT CAA CTA CAA-3'); ThrR (5'-ACC TCC GAT CTT CGG ATT ACA AGA CCG-3') (Machordom and Doadrio 2001). PCR reactions were carried out in a $30 \mu \mathrm{l}$ volume and amplifications proceeded for $5 \mathrm{~min}$ at $94^{\circ} \mathrm{C}$ followed by 34 cycles of $95^{\circ} \mathrm{C}$ for $30 \mathrm{~s}, 55^{\circ} \mathrm{C}$ for $30 \mathrm{~s}, 72^{\circ} \mathrm{C}$ for $60 \mathrm{~s}$ and final extension at $72^{\circ} \mathrm{C}$ for $10 \mathrm{~min}$. The PCR products were sent to a commercial corporation for sequencing. The nucleotide sequences were assembled from independent sequence passes using the SeqMan (Swindell and Plasterer 1997) module of the DNAStar software package. Additionally, sequences for other species of Homatula were obtained from GenBank (Endruweit et al. 2018, Min et al. 2012, Xiong et al. 2017, Yue et al. 2013). Thirteen species of Homatula were studied, from which 680-bp COI sequences of 50 samples and 1,120-bp Cyt $b$ sequences of 42 samples were used to identify the new species. A list of taxa with corresponding GenBank accession numbers is presented in Table 1. Phylogenetic analysis was performed using PhyloSuite (Zhang et al. 2020). Multiple alignments were performed with MAFFT version 7 with the default parameters (Katoh and Standley 2013). Then, ModelFinder (Kalyaanamoorthy et al. 2017) was used to ascertain the best-fit model of nucleotide substitution for the sequences using the AIC. Tree analyses were performed under Bayesian Inference (BI). All Bayesian phylogenetic analyses were conducted with MrBayes 3.2 (Ronquist et al. 2012), based on the GTR+F+G4 model estimated by ModelFinder. Four Markov chains were run for $1,000,000$ generations to estimate the posterior probability distribution, sampling every 1000 generations. After discarding the first 1000 trees as a burn-in with non-stationary log likelihood values, $50 \%$ majority-rule consensus trees were estimated for the remaining trees. Finally, all sequences were grouped according to the results of the phylogenetic analysis. The genetic distances between groups were calculated using MEGA7.0 (Kumar et al. 2016), based on the K2P model. 
Table 1.

GenBank accession numbers of $\mathrm{COI}$ and Cyt $b$ sequences.

\begin{tabular}{|c|c|c|}
\hline Species & COI Gene Accession Numbers & Cyt $b$ Gene Accession Numbers \\
\hline \multirow[t]{4}{*}{ H. longidorsalis } & MF953196* & HM010550* \\
\hline & ${\underline{M F 953197^{*}}}$ & $\underline{\mathrm{HM} 010551^{*}}$ \\
\hline & & HM010552* \\
\hline & & $\underline{\mathrm{HM}}^{\mathrm{H} 10568^{*}}$ \\
\hline \multirow[t]{2}{*}{ H. anguillioides } & $\underline{M F 953178 *}^{*}$ & \\
\hline & MF953184* & \\
\hline \multirow[t]{4}{*}{ H. acuticephala } & & $\underline{\mathrm{HM}} 010526^{*}$ \\
\hline & & $\underline{\mathrm{HM}}^{\mathrm{HM} 10505^{*}}$ \\
\hline & & $\underline{\mathrm{HM}} 10527^{*}$ \\
\hline & & $\underline{\mathrm{HM}} 10528^{*}$ \\
\hline \multirow[t]{2}{*}{ H. berezowskii } & & $\mathrm{KX} 394259^{*}$ \\
\hline & & 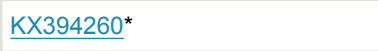 \\
\hline \multirow[t]{5}{*}{ H. coccinocola } & ${\underline{M F 953208^{*}}}^{*}$ & \\
\hline & MF953209* $^{*}$ & \\
\hline & MF953210* & \\
\hline & $\underline{\text { MF953211* }}^{*}$ & \\
\hline & MF953212* $^{*}$ & \\
\hline \multirow[t]{4}{*}{ H. disparizona } & $\underline{\text { MF953190* }}$ & \\
\hline & $\underline{\text { MF953193* }}$ & \\
\hline & $\underline{\text { MF953194* }}$ & \\
\hline & $\underline{\text { MF953195* }}$ & \\
\hline \multirow[t]{5}{*}{ H. potanini } & $\underline{\text { MF953199* }}$ & $\underline{\mathrm{JF} 340396 *}^{*}$ \\
\hline & $\underline{\text { MF953200* }}$ & ${\underline{\mathrm{JF} 340397^{*}}}^{*}$ \\
\hline & $\underline{\text { MF953201* }}$ & ${\underline{\mathrm{JF} 340398^{*}}}$ \\
\hline & & ${\underline{\mathrm{JF} 340399^{*}}}$ \\
\hline & & ${\underline{\mathrm{JF} 340400^{*}}}$ \\
\hline \multirow[t]{4}{*}{ H. pycnolepis } & MF953202* & ${\underline{\mathrm{KF}} 040997^{*}}^{*}$ \\
\hline & $\underline{\text { MF953205* }^{*}}$ & ${\mathrm{KF} 040998^{*}}^{*}$ \\
\hline & MF953206* & $\underline{\text { KF040999* }}$ \\
\hline & $\underline{\mathrm{MF}}$ & \\
\hline \multirow[t]{4}{*}{ H. variegata } & MF953216* & $\underline{\mathrm{KX}} 394267^{*}$ \\
\hline & $\underline{\mathrm{MF}}$ & $\underline{K X 394268}^{*}$ \\
\hline & $\underline{\text { MF953218* }}$ & $\underline{\mathrm{KX}} 394269^{*}$ \\
\hline & MF953219* & ${\underline{\mathrm{KX}} 394270^{*}}^{*}$ \\
\hline
\end{tabular}




\begin{tabular}{|c|c|c|}
\hline Species & COI Gene Accession Numbers & Cyt $b$ Gene Accession Numbers \\
\hline \multirow[t]{3}{*}{ H. wuliangensis } & $\underline{\text { MF953220* }}^{*}$ & \\
\hline & $\underline{\text { MF953221* }}$ & \\
\hline & MF953222* & \\
\hline H. guanheensis sp. nov & $\underline{\text { MT771689-MT771705 }}$ & $\underline{\text { MT771706-MT1722 }}$ \\
\hline Schistura latifasciata & MF953223* & JN837653* \\
\hline
\end{tabular}

* Sequences were retrieved from GenBank.

\section{Data resources}

All the sequences in this study were retrieved from GenBank and the accession numbers of the newly determined sequences in this study are MT771689-MT771705 (COI) and MT771706-MT1722 (Cyt b).

\section{Taxon treatment}

Homatula guanheensis C. J. Zhou, W. W. Ma, Xi Wang, Y.T. Tang, X.L. Meng and G.X. Nie, 2021, sp. n.

\section{- ZooBank 5B17C202-F739-4EB6-BF82-1FF6CDCA25A9}

\section{Materials}

Holotype:

a. $\quad$ scientificName: Homatula guanheensis; kingdom: Animalia; phylum: Chordata; class: Actinopterygii; order: Cypriniformes; family: Nemacheilidae; subgenus: Homatula; waterBody: the Yangtze River; country: China; stateProvince: Henan Province; county: Xixia County; locality: the Guanhe River, a tributary of the Hanjiang River drainage;

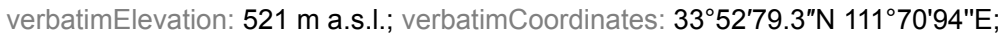
georeferenceSources: Google Earth; eventDate: 21/03/2017; individualCount: 1; sex: female; lifeStage: adult; behavior: cave environment scoured by flowing water; recordNumber: HNU 010048; recordedBy: Henan Provincial Fish Resources Investigation Team; identifiedBy: Chuan-Jiang Zhou; dateldentified: 03/21/2017; collectionCode: fish; basisOfRecord: Preserved Specimen

\section{Paratypes:}

a. $\quad$ scientificName: Homatula guanheensis; waterBody: the Yangtze River; country: China; stateProvince: Henan Province; county: Xixia County; locality: the Guanhe River, a tributary of the Hanjiang River drainage; verbatimElevation: $522 \mathrm{~m}$; verbatimCoordinates: $33^{\circ} 52^{\prime} 79.3^{\prime \prime} \mathrm{N} 111^{\circ} 70^{\prime} 95 " \mathrm{E}$; georeferenceSources: Google Earth; eventDate: 21/03/2017; individualCount: 8; lifeStage: adult; behavior: cave environment scoured by flowing water; recordNumber: HNU 010049-HNU 010056; recordedBy: Henan Provincial Fish Resources Investigation Team; identifiedBy: Chuan-Jiang Zhou; dateldentified: 03/22/2017; collectionCode: fish; basisOfRecord: Preserved Specimen

b. ScientificName: Homatula guanheensis; waterBody: the Yangtze River; country: China; stateProvince: Henan Province; county: Xixia County; locality: the Guanhe River , a 
tributary of the Hanjiang River drainage; verbatimElevation: 523 m; verbatimCoordinates: $33^{\circ} 52^{\prime} 79.3^{\prime \prime} \mathrm{N} 111^{\circ} 70^{\prime} 96 " \mathrm{E}$; georeferenceSources: Google Earth; individualCount: 1; sex: female; lifeStage: adult; behavior: cave environment scoured by flowing water; recordNumber: HNU 010060; recordedBy: Henan Provincial Fish Resources Investigation Team; identifiedBy: Chuan-Jiang Zhou; dateldentified: 23/03/2017; collectionCode: fish; basisOfRecord: Preserved Specimen

\section{Description}

Body elongate, anterior portion nearly cylindrical and posterior portion compressed; body depth $11.63 \%(10.41-13.47 \%$ ) in SL (Table 2). Body scales, back and sides of post-dorsal body closely covered by small scales, predorsal body scales sparse; head, thorax and abdomen scaleless. Lateral line straight, complete and mid-lateral. Vertebrae count 4+41-43. Head short and depressed, naked, wider $56.07 \%(49.39 \%-$ $61.12 \%)$ in $\mathrm{HL}$ than high $45.77 \%(42.42 \%-49.95 \%)$ in $\mathrm{HL}$. Snout blunt, length $40.75 \%$ (34.48\%-44.35\%) in HL (Table 2). Anterior nostril forms a valve, nostril closer to anterior margin of eye than to snout tip. Eyes oval, closer to snout tip, indiscernible from ventral view. Interorbital width $28.47 \%(23.89 \%-31.09 \%)$ in HL (Table 2). Mouth inferior, lips thick and furrowed, jaws covered by lips, upper jaw with developed processus dentiformis corresponding with marked median notch on lower jaw. Three pairs of barbels: two rostral barbels, inner pair not reaching mouth corner and outer pair reaching vertical line of anterior nostril; one maxillary barbel extending to the middle and posterior margin of eye (Fig. 1). Dorsal fin iii, $7-8^{1 /}{ }_{2}$ rays, origin nearer to snout tip than to caudal-fin base. Pectoral fin i, 9-10 rays, not extending beyond halfway from its origin to the pelvic-fin origin. Pelvic fin i, 6-7 rays, its origins closer to vertical line of first branched rays of dorsal fin; tip of the pelvic fin not extending beyond half the distance from its origin to anal fin origin. Anal fin iii, $5^{1 /}{ }_{2}$ rays; origin of anal fin closer to pelvic fin origin than to caudal fin base, its tip not reaching half distance from anal-fin origin to caudal-fin base. Posterior margin of caudal fin micro-rounded; adipose crests along its dorsal and ventral mid-lines without extending through the origin of anal fin. Intestine formed as a bend, not reaching posterior surface of the U-shaped stomach. Gas bladder osseous, anterior chamber invisible, fully enclosed in a capsule; posterior chamber degenerated.

Table 2.

Trials and morphometric characters of Homatula guanheensis sp. nov.

\begin{tabular}{|c|c|c|c|c|}
\hline & \multirow[t]{2}{*}{ Holotype } & \multicolumn{3}{|c|}{ Paratypes $(n=9)$} \\
\hline & & range & mean & SD \\
\hline Standard length (mm) & 99.6 & $76.9-109.26$ & 91.8 & \\
\hline \multicolumn{5}{|l|}{ As\%SL } \\
\hline Body depth & 11.6 & $10.4-13.4$ & 11.9 & 0.8 \\
\hline Head length & 18.5 & $17.3-20.3$ & 18.7 & 0.9 \\
\hline
\end{tabular}




\begin{tabular}{|c|c|c|c|c|c|c|}
\hline & \multicolumn{3}{|c|}{ Holotype } & \multicolumn{3}{|c|}{ Paratypes $(n=9)$} \\
\hline & & & & range & mean & SD \\
\hline Dorsal-fin length & \multicolumn{3}{|l|}{18.5} & $17.3-21.3$ & 19.3 & 1.3 \\
\hline Pectoral-fin length & \multicolumn{3}{|l|}{12.9} & $11.4-14.2$ & 12.7 & 0.9 \\
\hline Pelvic-fin length & \multicolumn{3}{|l|}{10.5} & $10.3-12.7$ & 11.4 & 0.8 \\
\hline Anal-fin length & \multicolumn{3}{|l|}{13.4} & $11.6-14.1$ & 13 & 0.8 \\
\hline Predorsal length & \multicolumn{3}{|l|}{46.5} & $42.3-49.1$ & 45.7 & 2.3 \\
\hline Pre-anus length & \multicolumn{3}{|l|}{18.1} & $16.4-20.2$ & 18.4 & 1.3 \\
\hline Prepelvic length & \multicolumn{3}{|l|}{47.2} & $43.9-49.3$ & 46.7 & 1.2 \\
\hline Pre-anal length & \multicolumn{3}{|l|}{72.7} & $68.8-73.4$ & 71.1 & 2 \\
\hline Caudal peduncle depth & \multicolumn{3}{|l|}{13.6} & $10.1-13.6$ & 11.3 & 1.2 \\
\hline Caudal peduncle length & \multicolumn{3}{|l|}{20.9} & $16.4-23.6$ & 20.2 & 1.8 \\
\hline \multicolumn{7}{|c|}{ As\%Caudal peduncle length } \\
\hline \multicolumn{2}{|l|}{ Caudal peduncle depth } & 65.1 & \multicolumn{2}{|l|}{ 45.7-76.8 } & 56.6 & 8.9 \\
\hline \multicolumn{7}{|l|}{ As\%HL } \\
\hline \multicolumn{2}{|l|}{ Head depth } & 43.4 & \multicolumn{2}{|l|}{ 42.4-49.9 } & 45.8 & 2.6 \\
\hline \multicolumn{2}{|l|}{ Head width } & 53.7 & \multicolumn{2}{|l|}{ 49.3-61.1 } & 56.1 & 3.7 \\
\hline \multicolumn{2}{|l|}{ Eye diameter } & 14.6 & \multicolumn{2}{|l|}{$12.2-16.9$} & 14.6 & 1.2 \\
\hline \multicolumn{2}{|l|}{ Snout length } & 40.1 & \multicolumn{2}{|l|}{$34.4-44.3$} & 40.7 & 3.5 \\
\hline \multicolumn{2}{|l|}{ Interorbital width } & 29.9 & \multicolumn{2}{|l|}{ 23.8-31.1 } & 28.5 & 2.2 \\
\hline
\end{tabular}

\section{Table 3.}

Component matrix of the Principal Component Analysis from morphometric data of $H$. guanheensis and $H$. laxiclathra.

\begin{tabular}{|l|l|l|l|}
\hline & PC1 & PC2 & PC3 \\
\hline Body depth & 0.156 & 0.126 & 0.889 \\
\hline Head length & 0.851 & 0.264 & 0.229 \\
\hline Head depth & 0.515 & -0.088 & 0.46 \\
\hline Head width & 0.136 & -0.074 & 0.099 \\
\hline Eye diameter & 0.807 & -0.041 & 0.384 \\
\hline Interorbital width & 0.137 & 0.91 & 0.045 \\
\hline Snout length & 0.701 & 0.148 & 0.036 \\
\hline Dorsal-fin length & 0.015 & 0.976 & -0.172 \\
\hline
\end{tabular}




\begin{tabular}{|l|l|l|l|}
\hline & PC1 & PC2 & PC3 \\
\hline Pectoral-fin length & 0.78 & 0.094 & 0.31 \\
\hline Pelvic-fin length & 0.683 & 0.527 & 0.196 \\
\hline Anal-fin length & 0.182 & 0.961 & -0.078 \\
\hline Predorsal length & 0.346 & 0.054 & 0.724 \\
\hline Prepelvic length & 0.292 & -0.09 & 0.753 \\
\hline Prepectoral length & 0.481 & 0.095 & 0.606 \\
\hline Pre-anal length & 0.621 & -0.161 & 0.333 \\
\hline Caudal peduncle length & -0.235 & 0.817 & 0.229 \\
\hline Caudal peduncle depth & -0.681 & 0.111 & -0.447 \\
\hline Cumulative variance (\%) & 59.35 & 79.65 & 85.10 \\
\hline
\end{tabular}

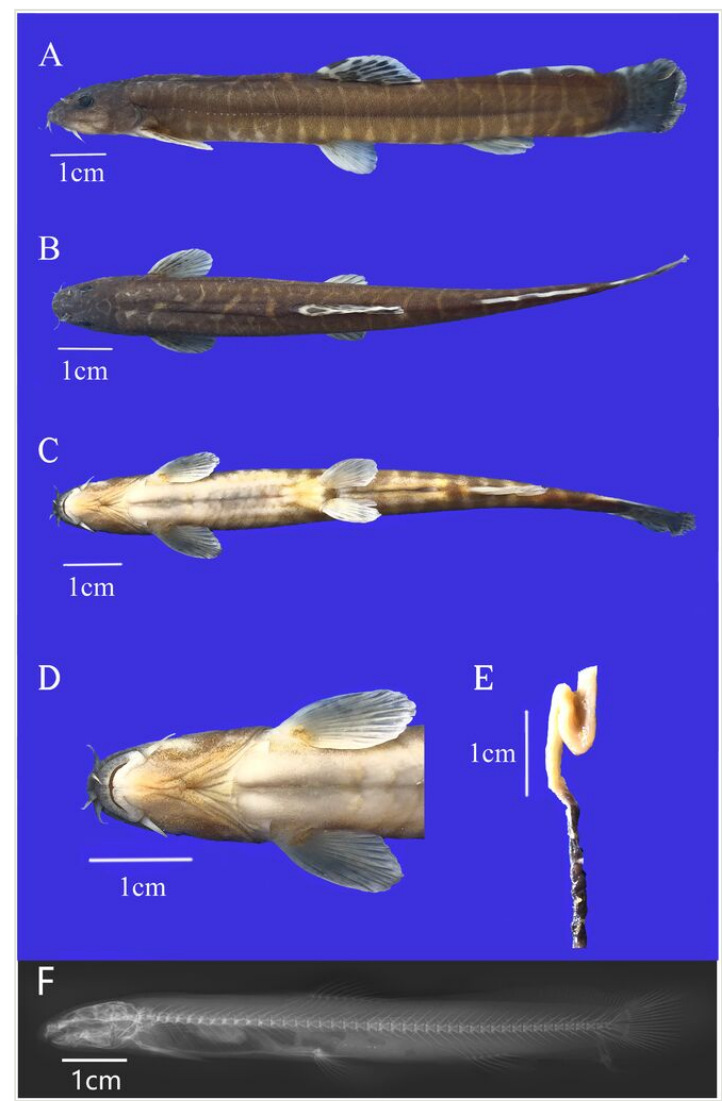

Figure 1. doi

Homatula guanheensis (holotype, HNU 010048, 99.6 mm SL). A. Lateral view; B. Dorsal view; C. Ventral view; D. Mouth characters; E. Intestine form; F. X-ray (lateral view). 

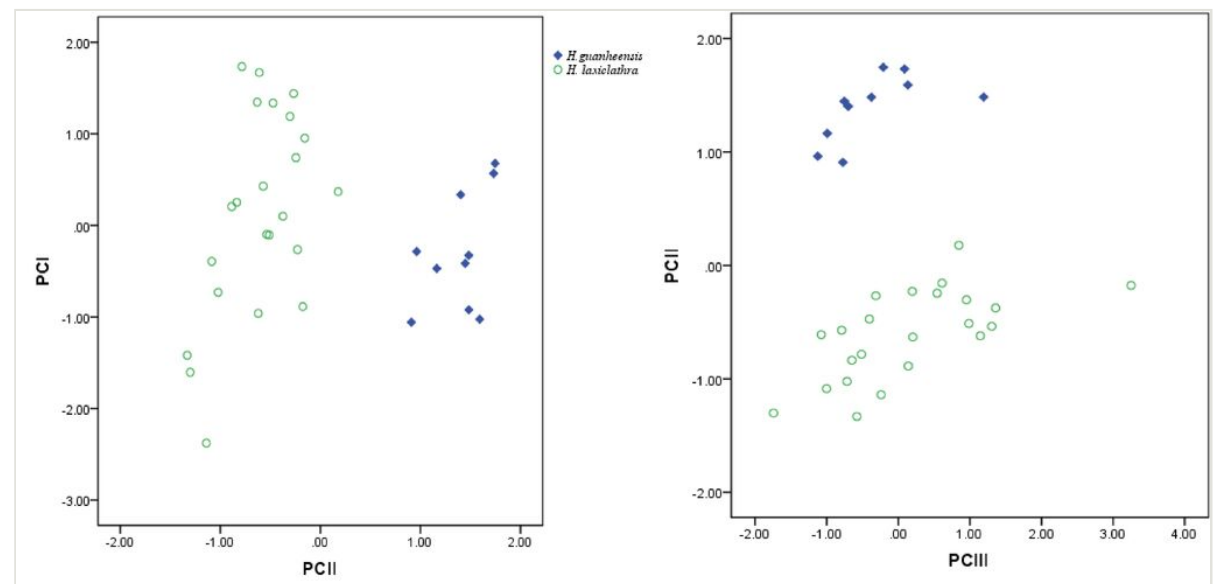

Figure 2. doi

Scatter plots of the first and second principal components from morphometric data of $H$. guanheensis $(n=10,76.9-109.26 \mathrm{~mm} \mathrm{SL})$ and $H$. laxiclathra $(n=23,67.6-136.7 \mathrm{~mm} \mathrm{SL})$.

Color in preserved specimens (fixed in 10\% formalin): Head and body brown; a series of 19-22 body bars, each bar at least twice as wide as the interspace. Abdomen yellowish. Dorsal fin with two dark brown marks, one at the base, the other at postmedian of the fin; posterior border of dorsal fin white. Pectoral fins with dark brown spots. Pelvic and anal fins white, dark at the base. Adipose keels white with dark brown spots. Caudal fin dark grey; brown vertical bars on caudal fin base (Fig. 1).

\section{Diagnosis}

Homatula guanheensis is different from its congeners in the following characters: partly scaled (vs. in the latter, scales are totally absent or only a few scales on the caudal peduncle in $H$. nanpanjiangensis, $H$. oligolepis, $H$. disparizona and $H$. wenshanensis vs. scales all over the body, except for the head in $H$. acuticephala, $H$. anguillioides, $H$. pycnolepis, $H$. wuliangensis, $H$. change and $H$. coccinocola); complete lateral line (vs. incomplete lateral line in $H$. potanini and $H$. wujiangensis); the vertical brown bars on the body are wider than their interspaces, numbering 19-22 (vs. equal to interspace or slightly wider than its interspace in $H$. variegate, $H$. berezowskii and $H$. longidorsalis); caudal fin micro-rounded (vs. truncated or oblique in $H$. variegata and $H$. berezowskii); adipose crest on caudal peduncle not reaching forward of the position of the anal-fin origin (vs. beyond in $H$. variegate vs. identical in $H$. longidorsalis); predorsal body partially scaled (vs. absent scales in $H$. berezowskii and $H$. longidorsalis); anterior nostril forming a valve (vs. forming a spool in $H$. longidorsalis). The vertical brown bars on the body of the new species are similar to $H$. laxiclathra. The new species can be further distinguished from $\mathrm{H}$. laxiclathra in that the intestine forms a bend, not reaching the posterior surface of U-shaped stomach (vs. a loop anteriorly reaching the posterior surface of the U-shaped stomach); anterior with only a few and scattered scales (vs. scaleless). 


\section{Etymology}

The specific epithet Guanheensis is derived from Guanhe River (鹳河 in Chinese, type locality) with the Latin suffix "-ensis".

\section{Distribution}

Homatula guanheensis sp. nov. is known from the Guanhe River of the Hanjiang River drainage (a tributary of the Yangtze River) in Henan Province, Central China (Fig. 3).

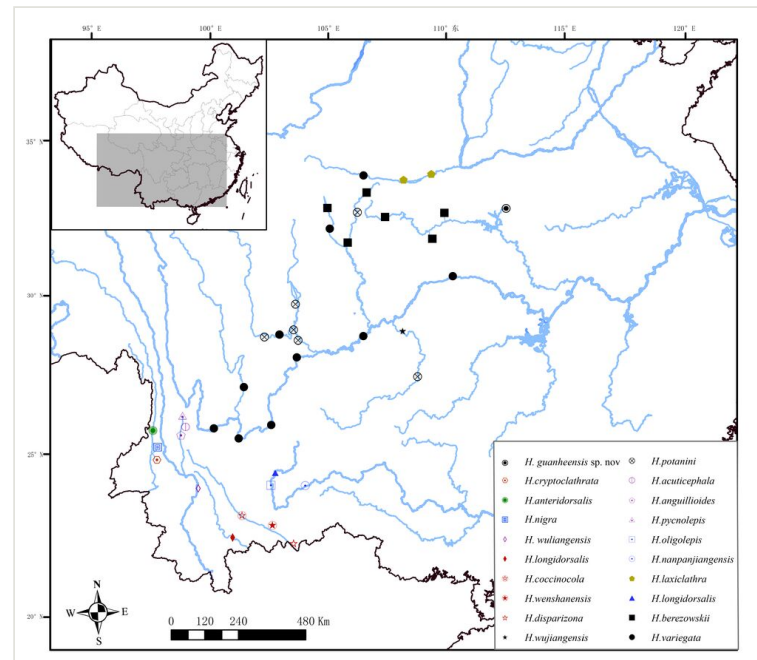

Figure 3. doi

Distribution of all species of Homatula in China.

\section{Identification keys}

\section{Keys to species of the genus Homatula in China}

\begin{tabular}{|l|l|l|}
\hline 1 & Lateral line incomplete & 2 \\
\hline- & Lateral line complete & 3 \\
\hline 2 & $\begin{array}{l}\text { Scales present; covering whole body except head and abdomen; } \\
\text { dorsal crest high and long, from dorsal-fin base to caudal-fin base } \\
\text { (Jinshajiang River, Sichuan Province) }\end{array}$ & $\begin{array}{l}\text { H. potanini (Günther, } \\
1896)\end{array}$ \\
\hline$-\quad \begin{array}{l}\text { Body scaleless or with rudimentary scales; dorsal crest high and } \\
\text { short, upper crest not reaching the posterior point of anal-fin base } \\
\text { (Wujiang River, Sichuan Province) }\end{array}$ & $\begin{array}{l}\text { H. wujiangensis (Ding } \\
\text { \& Deng, 1990) }\end{array}$ \\
\hline
\end{tabular}




\begin{tabular}{|c|c|c|}
\hline 3 & $\begin{array}{l}\text { Anterior ending of adipose crest does not reach posterior end of } \\
\text { anal-fin base }\end{array}$ & 4 \\
\hline- & Anterior ending of adipose crest reach posterior end of anal-fin base & 7 \\
\hline 4 & $\begin{array}{l}\text { The length of dorsal-fin base longer than the longest branched } \\
\text { dorsal-fin ray (Nujiang River, Yunnan Province) }\end{array}$ & $\begin{array}{l}\text { H. cryptoclathrata ( } \mathrm{Li} \\
\text { et al., 2019) }\end{array}$ \\
\hline- & $\begin{array}{l}\text { The length of dorsal-fin base shorter than the longest branched } \\
\text { dorsal-fin ray }\end{array}$ & 5 \\
\hline 5 & Having clear pattern of marks on the flank & 6 \\
\hline- & No marks on the flank (Nujiang River, Yunnan Province) & $\begin{array}{l}\text { H. nigra (Li et al., } \\
\text { 2019) }\end{array}$ \\
\hline 6 & $\begin{array}{l}\text { 27-34 marks on the flank; dorsal and pelvic fins closer to snout } \\
\text { (Nujiang River, Yunnan Province) }\end{array}$ & $\begin{array}{l}\text { H. anteridorsalis (Li et } \\
\text { al., 2019) }\end{array}$ \\
\hline- & $\begin{array}{l}20-22 \text { marks on the flank; dorsal and pelvic fins located intermediate } \\
\text { of body (Mengyejiang River, Yunnan Province) }\end{array}$ & $\begin{array}{l}\text { H. change (Endruweit, } \\
\text { 2015) }\end{array}$ \\
\hline 7 & Scales are totally absent or only a few scales on the caudal peduncle & 8 \\
\hline- & Scales clearly present, covering posterior of body at least & 11 \\
\hline 8 & No median notch on lower jaw & 9 \\
\hline- & Median notch on lower jaw & 10 \\
\hline 9 & $\begin{array}{l}\text { The caudal fin emarginate; caudal peduncle narrow and long; } \\
\text { vertebrae } 4+39 \sim 40 \text { (Panlong River, Yunnan Province) }\end{array}$ & $\begin{array}{l}\text { H. disparizona (Min et } \\
\text { al., 2013) }\end{array}$ \\
\hline- & $\begin{array}{l}\text { The caudal fin furcate; caudal peduncle wider and shorter; vertebrae } \\
4+47 \sim 48 \text { (the Red River, Yunnan Province) }\end{array}$ & $\begin{array}{l}\text { H. wenshanensis } \\
\text { (Yang et al., 2017) }\end{array}$ \\
\hline 10 & $\begin{array}{l}\text { Body with regular vertical bars and bars in front of dorsal fin } \\
\text { conspicuously thinner than those behind; no vermiform markings on } \\
\text { parietal area or obscure; tip of pelvic fin closing or reaching anus } \\
\text { (Nanpanjiang River, Yunnan Province) }\end{array}$ & $\begin{array}{l}\text { H. nanpanjiangensis } \\
\text { (Min et al., 2010) }\end{array}$ \\
\hline- & $\begin{array}{l}\text { Body and head with vermiform markings; dorsal fin and pectoral fin } \\
\text { covered by small spots on both sides; tip of pelvic fin quite far away } \\
\text { from anus (Yangzonghai River, Yunnan Province) }\end{array}$ & $\begin{array}{l}\text { H. oligolepis (Cao \& } \\
\text { Zhu, 1989) }\end{array}$ \\
\hline 11 & Scales covering whole body, except head & 12 \\
\hline- & $\begin{array}{l}\text { Posterior part of the body covered by scales; anterior part scaleless } \\
\text { or with only a few and scattered scales }\end{array}$ & 16 \\
\hline
\end{tabular}




\begin{tabular}{|c|c|c|}
\hline 12 & Having pelvic axillary lobe & 13 \\
\hline- & Absent pelvic axillary lobeAbsent pelvic axillary lobe & 15 \\
\hline 13 & $\begin{array}{l}\text { A pair of free protrusions present in pelvic fins (Yangbijiang River, } \\
\text { Yunnan Province) }\end{array}$ & $\begin{array}{l}\text { H. pycnolepis (Hu \& } \\
\text { Zhang, 2010) }\end{array}$ \\
\hline- & Absent free protrusions in pelvic fins & 14 \\
\hline 14 & $\begin{array}{l}\text { Caudal fin slightly emarginated to nearly truncate; having notch on } \\
\text { the lower jaw; } 16-19 \text { brown bars on a beige background, bars are } \\
\text { somewhat straight and never vertically split, notch on the lower jaw } \\
\text { (Tengtiaojiang River, Yunnan Province) }\end{array}$ & $\begin{array}{l}\text { H. coccinocola (Min et } \\
\text { al., 2018) }\end{array}$ \\
\hline- & $\begin{array}{l}\text { Caudal fin rounded; lacking notch on the lower jaw; } 22-26 \text { brown } \\
\text { bars on body (Lancang River, Yunnan Province) }\end{array}$ & $\begin{array}{l}\text { H. wuliangensis (Min } \\
\text { et al., 2012) }\end{array}$ \\
\hline 15 & $\begin{array}{l}\text { Caudal fin truncated; body depth extremely decreased posterior of } \\
\text { dorsal-fin base; head sharp (Haixihai Lake, Yunnan Province) }\end{array}$ & $\begin{array}{l}\text { H. acuticephala (Zhou } \\
\& \text { He, 1993) }\end{array}$ \\
\hline- & $\begin{array}{l}\text { Caudal fin oblique; body depth quite uniform from head to tail; head } \\
\text { blunt (Mekong River, Yunnan Province) }\end{array}$ & $\begin{array}{l}\text { H. anguillioides (Zhu } \\
\text { \& Wang, 1985) }\end{array}$ \\
\hline 16 & $\begin{array}{l}\text { Anterior nostrils pierced in front side of a tube; dorsal fin is far from } \\
\text { the snout (Nanpangjiang River, Yunnan Province) }\end{array}$ & $\begin{array}{l}\text { H. longidorsalis (Yang } \\
\text { et al., 1989) }\end{array}$ \\
\hline- & $\begin{array}{l}\text { Anterior nostrils pierced in front side of a flap, dorsal fin closer to the } \\
\text { snout }\end{array}$ & 17 \\
\hline 17 & Vertical brown bars narrower or slightly wider than their interspaces & 18 \\
\hline- & Vertical brown bars distinctly wider than interspaces & 19 \\
\hline 18 & $\begin{array}{l}\text { Caudal fin oblique; intestine forming a single loop; adipose crest of } \\
\text { the caudal peduncle anteriorly extending through the anal-fin origin } \\
\text { (Jinshajiang River, Weihe River) }\end{array}$ & $\begin{array}{l}\text { H. variegata (Sanvage } \\
\text { \& Dabry, 1874) }\end{array}$ \\
\hline- & $\begin{array}{l}\text { Caudal fin truncate; intestine forming a zigzag loop; adipose crest of } \\
\text { the caudal peduncle anteriorly not extending through the anal-fin } \\
\text { origin (Jialingjiang River, Gansu Province) }\end{array}$ & $\begin{array}{l}\text { H. berezowskii } \\
\text { (Günther, 1896) }\end{array}$ \\
\hline 19 & $\begin{array}{l}\text { Caudal fin oblique; intestine with a loop anteriorly reaching the } \\
\text { posterior surface of the U-shaped stomach; anterior scaleless } \\
\text { (Weihe River, Shaanxi Province) }\end{array}$ & $\begin{array}{l}\text { H. laxiclathra (Gu \& } \\
\text { Zhang, 2012) }\end{array}$ \\
\hline- & $\begin{array}{l}\text { Caudal fin micro-rounded; intestine forming a bend; anterior with only } \\
\text { a few and scattered scales (Guan River, Henan Province) }\end{array}$ & $\begin{array}{l}\text { H. guanheensis sp. } \\
\text { nov. }\end{array}$ \\
\hline
\end{tabular}




\section{Analysis}

\section{Genetic distance and phylogentic trees}

Based on the $\mathrm{COI}$ gene, sequences of 11 studied species were used to construct a $\mathrm{BI}$ tree. The new species belonged to a different clade with strong high PP values (100\%, Fig. 4), the genetic distance being analysed by the Kimura 2-parameter model. The distance matrix and number of sequences, determined for each species, are shown in Table 4 and Table 5. Genetic distance between $H$. guanheensis and other given species displayed $4.7 \%-10.6 \%$ variation in the COI base pairs (Table 4). The smallest distance, $2.9 \%$ (5 vs. 9 ) was detected between $H$. pycnolepis and $H$. anguillioides. Based on the Cyt $b$ gene, the phylogenetic tree analysis showed that $H$. guanheensis is a monophyletic group with a high posterior probability value $(100 \%$; Fig. 5$)$. Through the results of the genetic distance analysis, we found that $H$. guanheensis differed from the acquired congeners by $4.2 \%-$ $10.3 \%$. The genetic distance between $H$. guanheensis and similar species exceeded $2 \%$ variation, while the intraspecific variation of $H$. guanheensis was $0 \%$ (Table 5).

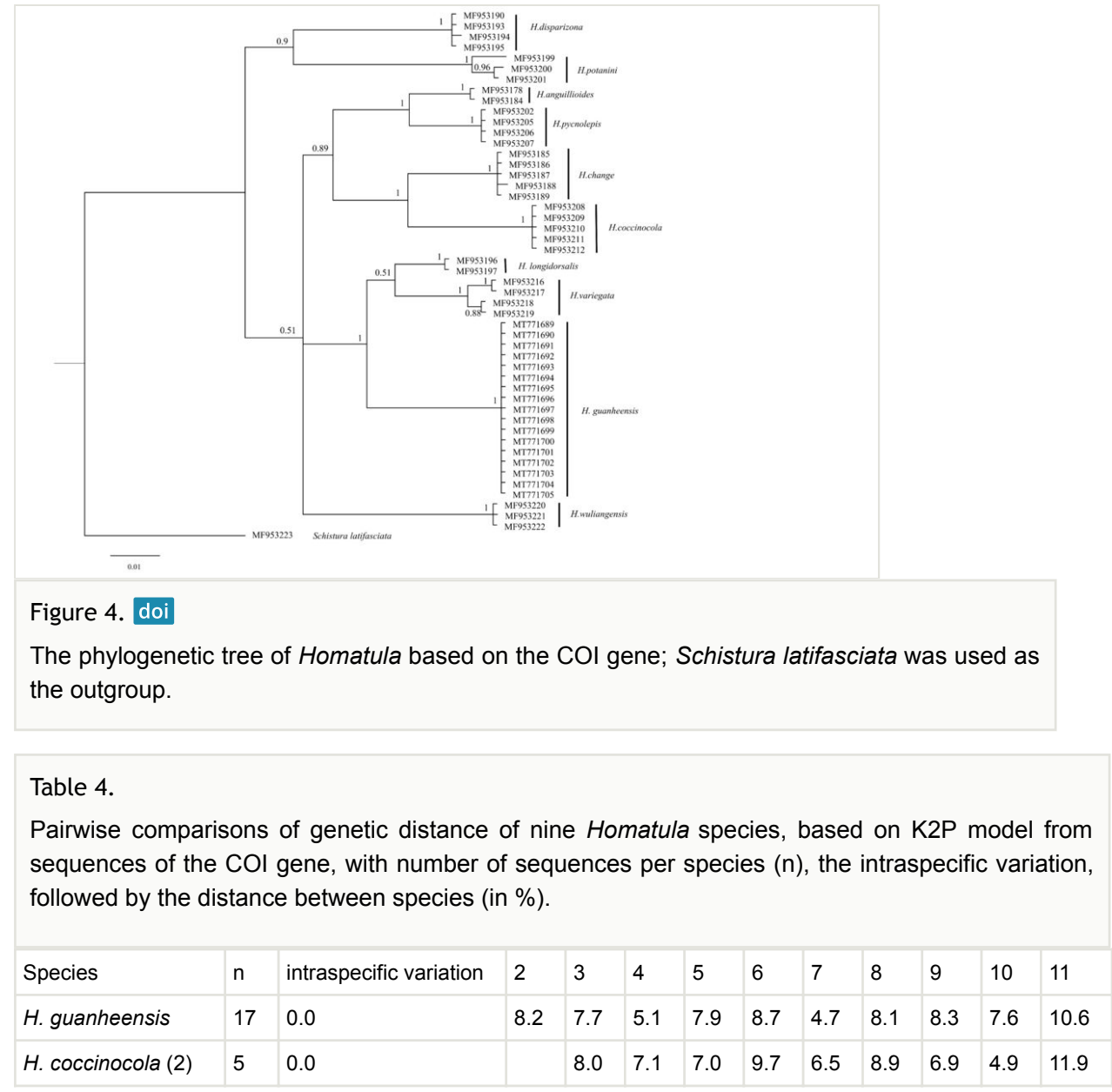




\begin{tabular}{|c|c|c|c|c|c|c|c|c|c|c|c|c|}
\hline Species & $\mathrm{n}$ & intraspecific variation & 2 & 3 & 4 & 5 & 6 & 7 & 8 & 9 & 10 & 11 \\
\hline H. wuliangensis (3) & 3 & 0.0 & & & 6.5 & 7.3 & 9.8 & 6.7 & 8.9 & 7.5 & 6.3 & 10.5 \\
\hline H. variegata (4) & 4 & 0.5 & & & & 7.2 & 8.1 & 3.2 & 7.4 & 6.8 & 6.2 & 10.5 \\
\hline H. pycnolepis (5) & 4 & 0.0 & & & & & 7.2 & 6.2 & 8.4 & 2.9 & 6.4 & 10.0 \\
\hline H. potanini (6) & 3 & 0.9 & & & & & & 7.2 & 8.0 & 7.4 & 8.4 & 10.2 \\
\hline H. longidorsalis (7) & 2 & 0.0 & & & & & & & 7.1 & 6.2 & 5.9 & 9.6 \\
\hline H. disparizona (8) & 4 & 0.1 & & & & & & & & 8.3 & 8.3 & 10.0 \\
\hline H. anguillioides (9) & 2 & 0.0 & & & & & & & & & 6.2 & 10.3 \\
\hline H. change (10) & 5 & 0.0 & & & & & & & & & & 11.1 \\
\hline S. latifasciata (11) & 1 & & & & & & & & & & & \\
\hline
\end{tabular}

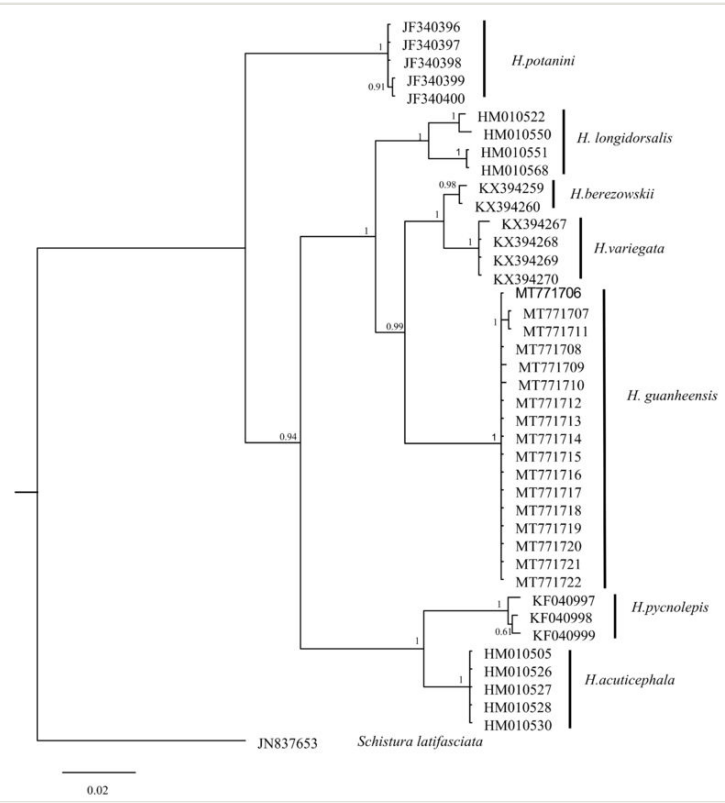

Figure 5. doi

The phylogenetic tree of Homatula based on the Cyt $b$ gene; Schistura latifasciata was used as the outgroup.

Table 5.

Pairwise comparisons of genetic distance of six Homatula species, based on K2P model from sequences of the Cyt $b$ gene, the other annotations being the same as Table 4.

\begin{tabular}{|l|l|l|l|l|l|l|l|l|l|}
\hline Species & $\mathrm{n}$ & intraspecific variation & 12 & 13 & 14 & 15 & 16 & 17 & 18 \\
\hline H. guanheensis & 17 & 0.1 & 4.8 & 10.3 & 9.9 & 4.2 & 5.8 & 9.5 & 15.8 \\
\hline H. variegata (12) & 4 & 0.1 & & 9.8 & 9.3 & 1.6 & 4.9 & 9.3 & 14.7 \\
\hline H. pycnolepis (13) & 3 & 0.4 & & & 10.3 & 9.5 & 9.2 & 4.0 & 15.4 \\
\hline
\end{tabular}




\begin{tabular}{|c|c|c|c|c|c|c|c|c|c|}
\hline Species & $\mathrm{n}$ & intraspecific variation & 12 & 13 & 14 & 15 & 16 & 17 & 18 \\
\hline H. potanini (14) & 5 & 0.1 & & & & 8.7 & 8.7 & 9.2 & 13.6 \\
\hline H. berezowskii (15) & 2 & 0.2 & & & & & 4.7 & 8.5 & 14.5 \\
\hline H. longidorsalis (16) & 4 & 1.5 & & & & & & 8.2 & 14.3 \\
\hline H. acuticephala (17) & 5 & 0.0 & & & & & & & 14.3 \\
\hline S. latifasciata (18) & 1 & & & & & & & & \\
\hline
\end{tabular}

\section{Discussion}

New species were collected from the Guanhe River of the Hanjiang River drainage (the middle and lower reaches of the Yangtze River). In terms of geographic distribution, the known species in the Yangtze River Basin are as follows: Homatula variegata, $H$. wujiangensis, $H$. berezowskii and $H$. potanini. $H$. variegata and $H$. potanini are mainly distributed in the upper reaches of the Yangtze River, while $H$. berezowskii is mainly distributed in the Jialingjiang River and the Hanjiang River (Zhu 1989, Yang et al. 1994, Hu and Zhang 2010). Zeng studied the samples of Homatula in the Yangtze River and the Yellow River and pointed out that there were differences in interorbital width and caudal peduncle length between $H$. berezowskii specimens of the Hanjiang River and the Jialingjiang River (Zeng et al. 2012). The new species was initially thought to belong to $H$. berezowskii; however, this hypothesis was quickly abandoned due to the differences in morphology and molecular characters. $H$. guanheensis is distinguished from $H$. berezowskii in having bars at least twice as wide as the interspace (vs. equal to the interspace or slightly wider than its interspace); scales partly on anterior body (vs. scaleless); intestine flat (vs. zigzag); a higher caudal peduncle, depth $11.3 \%(10.1 \%-$ $13.6 \%)$ in SL [vs. $10.0 \%(9.1 \%-10.9 \%)$ ] (Suppl. material 1). Besides this, they have significant divergence in genetic distance $(4.2 \%$, Cyt $b)$. The new species can be distinguished from other species in the Yangtze River Basin by the characteristics of the vertical brown bars, body scale distribution, adipose crest, intestine form and dorsal fin positions. $H$. guanheensis can be clearly distinguished from $H$. potanini and $H$. wujiangensis from the lateral line (complete vs. incomplete). It is distinct from $H$. variegata by having wider bars (vs. narrower), adipose keels not beyond the origin of anal-fin (vs. beyond), head flat, depth $45.8 \%(42.2 \%-49.9 \%)$ in $\mathrm{HL}$ [vs. 49.4\% (43.7\%-56.8\%)] (Suppl. material 1). Besides, the vertical brown bars on the body of the new species are similar to $H$. laxiclathra. The first two Principal Components of a processed Principal Component Analysis explained $85 \%$ of the variance (Fig. 2Table 3). Meanwhile, the new species can be further distinguished from $\mathrm{H}$. laxiclathra in having a flat intestine, not reaching posterior surface of the U-shaped stomach (vs. a loop anteriorly and reaching posterior surface); scales partly on anterior body (vs. scaleless); a wider interorbital width $28.5 \%(23.9 \%-$ $31.1 \%)$ in $\mathrm{HL}$ [vs. $22.5 \%(19.9 \%-24.9 \%)$ ]; a higher caudal peduncle, depth $11.3 \%(10.1 \%-$ $13.6 \%$ ) in SL [vs. $9.2 \%(8.4 \%-11.4 \%)$ ] (Suppl. material 1). Similar to H. longidorsalis, the new species has a slender body with uniform depth, while it differs from $H$. longidorsalis by having scales on the predorsal body (vs. scaleless on the predorsal body); anterior nostril forming a valve (vs. forming a spool); vertical brown bars at least twice as wide as 
interspace (vs. bars wider than interspace on anterior portion, unclear on posterior portion); adipose keels not beyond the origin of anal-fin (vs. identical); a shorter head, length $18.7 \%$ $(17.3 \%-20.3 \%)$ in SL [vs. 23.2\% (21.5\%-25.3\%)]; pelvic-fin close to tip of snout, prepelvic length $46.7 \%(43.9 \%-49.33 \%)$ in SL [vs. 52.6\% (50.5\%-56.7\%)] (Suppl. material 1).

According to the results of the phylogenetic tree, $H$. variegata, $H$. berezowskii, $H$. longidorsalis and the new species gather into a branch, $H$. longidorsalis and $H$. guanheensis $+(H$. berezowskii $+H$. variegata) form a sister group (supported by the Cyt $b$ gene, Fig. 5), but the new species and $H$. longidorsalis $+H$. variegata form a sister group (supported by the $\mathrm{COI}$ gene, Fig. 4). The cause might vary amongst datasets and, thus, this discordance might be influenced by stochastic errors associated with a different number of species and datasets (Naylor and Brown 1998). The results of Cyt $b$ data and the COI data show that the new species has a far genetic distance from $H$. berezowskii, $H$. variegata and $H$. longidorsalis.

\section{Acknowledgements}

This work was supported by the following funding: The National Natural Science Foundation of China (31872199, U2004146), Henan Province Department of Science and Technology (182102110046), The Training Plan for Young Teachers in Colleges and Universities of Henan Province (2019GGJS063). Study support was provided by The HighPerformance Computing Center of Henan Normal University. Thanks to Prof. E. Zhang from Institute of Hydrobiology, Chinese Academy of Sciences, Wuhan (IHB) for providing morphological data of $H$. laxiclathra.

\section{Author contributions}

Zhou Chuanjiang designed the study, analysed data and performed manuscript review, Ma Wenwen carried out the study, collected background information and drafted the manuscript. Zhou Chuanjiang, Meng Xiaolin, Wang Xi and Nie Guoxing collected samples in the field. All authors read and approved the final manuscript.

\section{References}

- Bănărescu P, Nalbant T (1995) A generical classification of Nemacheilinae with description of two new genera (Teleostei: Cypriniformes: Cobitidae). Travaux du Museum d'Histoire Naturelle "Grigore Antipa" 35: 429-495.

- Chu X, Chen Y (1990) The fishes of Yunnan, China. Science Press, Beijing.

- $\quad$ Ding R, Deng Q (1990) The Noemacheilinae fishes from Sichuan, with description of a new species I. Paracobitis, Nemacheilus and Oreias (Cypriniformes: Cobitidae).

Zoological Research 11 (4): 285-287. 
- $\quad$ Endruweit M (2015) Homatula change, a new nemacheilid loach from the upper Black River basin in Yunnan, China (Teleostei: Nemacheilidae). Ichthyological Exploration of Freshwaters 26: 65-72.

- $\quad$ Endruweit M, Min R, Yang J (2018) A new species of Homatula from the Red River drainage in Yunnan based on morphological and genetic data (Teleostei:

Nemacheilidae). Zootaxa 4375 (4): 555-566. https://doi.org/10.11646/zootaxa.4375.4.5

- Gu J, Zhang E (2011) Homatula laxiclathra (Teleostei: Balitoridae), a new species of nemacheiline loach from the Yellow River drainage in Shaanxi Province, northern China. Environmental Biology of Fishes 94 (4): 591-599. https://doi.org/10.1007/ s10641-011-9965-1

- $\quad \mathrm{Hu}$ YT, Zhang E (2010) Homatula pycnolepis, a new species of nemacheiline loach from the upper Mekong drainage, South China (Teleostei: Balitoridae). Ichthyological Exploration of Freshwaters 21 (1): 51-62.

- Kalyaanamoorthy S, Minh BQ, Wong TKF, von Haeseler A, Jermiin LS (2017) ModelFinder: fast model selection for accurate phylogenetic estimates. Nature Methods 14 (6): 587-589. https://doi.org/10.1038/nmeth.4285

- $\quad$ Katoh K, Standley DM (2013) MAFFT multiple sequence alignment software version 7: improvements in performance and usability. Molecular Biology and Evolution 30 (4):

772-780. https://doi.org/10.1093/molbev/mst010

- $\quad$ Kottelat M (1990) Indochinese Nemacheilines: A revision of nemacheiline loaches (Pisces, Cypriniformes) of Thailand, Burma, Laos, Cambodia and Southern Vietnam. 1991. Copeia

- Kumar S, Stecher G, Tamura K (2016) MEGA7: Molecular Evolutionary Genetics Analysis Version 7.0 for Bigger Datasets. Molecular Biology and Evolution 33 (7): 1870-1874. https://doi.org/10.1093/molbev/msw054\%20

- $\quad$ Li X, Che X, Zhou W, et al. (2019) Loaches of Homatula (Teleostei: Nemacheilidae) from the upper Salween River in Yunnan, China with description of three new species. Zootaxa 4711 (2): 330-348. [In English]. https://doi.org/10.11646/zootaxa.4711.2.6

- Machordom A, Doadrio I (2001) Evidence of a cenozoic Betic-Kabilian connection based on freshwater fish phylogeography (Luciobarbus, Cyprinidae). Molecular Phylogenetics and Evolution 18 (2): 252-263. https://doi.org/10.1006/mpev.2000.0876

- Min R, Chen X, Yang J (2010) Paracobitis nanpanjiangensis, a new loach (Balitoridae: Nemacheilinae) from Yunnan, China. Environmental Biology of Fishes 87 (3): 199-204. https://doi.org/10.1007/s10641-010-9587-z

- $\quad$ Min R, Xing YJ, Yong CX (2012) Homatula wuliangensis (Teleostei: Nemacheilidae), a new loach from Yunnan, China. Zootaxa (3586)313-318. https://doi.org/10.11646/ zootaxa.3586.1.29

- Min R, Yang JX, Chen XY (2013) Homatula disparizona, a new species of loach from the Red River drainage in China (Teleostei: Nemacheilidae) from China. Ichthyological Exploration of Freshwaters 23 (4): 351-355.

- $\quad$ Min RUI, Chen X, Yang J, Winterbottom R, Mayden R (2012) Phylogenetic relationships of the genus Homatula (Cypriniformes: Nemacheilidae), with special reference to the biogeographic history around the Yunnan-Guizhou Plateau. Zootaxa 3586 (1): 78-94. https://doi.org/10.11646/zootaxa.3586.1.9

- Naylor G, Brown W (1998) Amphioxus Mitochondrial DNA, Chordate Phylogeny, and the Limits of Inference Based on Comparisons of Sequences. Systematic Biology 47 (1): 61-76. https://doi.org/10.1080/106351598261030 
- $\quad$ Ronquist F, Teslenko M, van der Mark P, Ayres DL, Darling A, Hohna S, Larget B, Liu L, Suchard MA, Huelsenbeck JP (2012) MrBayes 3.2: efficient Bayesian phylogenetic inference and model choice across a large model space. Systematic Biology 61 (3): 539-542. https://doi.org/10.1093/sysbio/sys029

- Sambrook J, Fritsch E, Maniatis T (1989) Molecular cloning: a laboratory manual. Cold Spring Harbor Laboratory Press, Cold Spring Harbor, New York.

- Swindell S, Plasterer T (1997) Seqman: contig assembly. Methods in Molecular Biology 70: 75-89. https://doi.org/10.1385/0-89603-358-9:75.

- $\quad$ Xiong Y, Sun Z, Guo Y (2017) The revision of the classification of Homatula and Schistura in Sichuan Province. Journal of China West Normal University, Natural Sciences 38 (1): 21-27.

- Yang H, Li C, Liu T (2017) A report on a new species of Homatula from Yunnan (Cyprinifromes: Noemacheilidae). Journal of Yunnan Agricultural University (Natural Science) 32 (6): 1140-1144.

- Yang J, Chen Y, Kottelat M (1994) Subspecific differentiation of Paracobitis variegatus with comments on its zoogeography. Zoological Research 15: 58-67.

- Yue X, Liu S, Liu M, Duan X, Wang D, Chen D (2013) Age structure and genetic diversity of Homatula pycnolepis in the Nujiang River basin. Zoological Research 34 (4): 392-398.

- $\quad$ Zeng Y, Zhang E, GU J, Lin G, Zhang J (2012) Morphological variation in the loach species Homatula variegata (Balitoridae), with notes on its taxonomic status. Hubei Agricultural Sciences 51 (5): 972-976.

- Zhang D, Gao F, Jakovlic I, Zou H, Zhang J, Li WX, Wang GT (2020) PhyloSuite: An integrated and scalable desktop platform for streamlined molecular sequence data management and evolutionary phylogenetics studies. Molecular Ecology Resource 20 (1): 348-355. https://doi.org/10.1111/1755-0998.13096

- Zhou W, He J (1993) The Paracobitis distributed in Erhai area, Yunnan, China (Pisces: Cobitidae). Zoological Research 14: 5-9.

- Zhu S, Wang S (1985) The noemacheiline fishes from Yunnan Province, China (Cypriniformes: Cobitidae). Acta Zootaxonomica Sinica 10 (2): 208-220.

- Zhu S, Cao W (1988) Descriptions of two new species and a new subspecies of Noemacheilinae from Yunnan Province (Cypriniformes: Cobitidae). Acta Zootaxonomica Sinica 13: 95-100.

- Zhu S (1989) The loaches of the subfamily Nemacheilinae in China (Cypriniformes: Cobitidae). 1-150. Jiangsu Science \& Technology Press, Nanjing.

\section{Supplementary material}

\section{Suppl. material 1: Morphometric characters of Homatula variegata, $H$. berezowskii, $H$. longidorsalis and $\boldsymbol{H}$. laxiclathra from Gu and Zhang (2011). doi}

Authors: Gu and Zhang

Data type: morphological

Brief description: Morphometric characters of Homatula variegata, $H$. berezowskii, $H$. longidorsalis and $H$. laxiclathra from Gu and Zhang (2011), comparative materials with Table 2.

Download file $(11.82 \mathrm{~kb})$ 